\title{
PENINGKATAN KAPASITAS DAN EFISIENSI LINI TRIMMING DENGAN METODE MOODIE YOUNG DAN SIMULASI PROMODEL PADA PERAKITAN MOBIL BMW DI PT. GAYA MOTOR
}

\author{
Iveline Anne Marie ${ }^{1}$, Lamto Widodo $^{2}$ dan Michelle Melsha Sugiarto ${ }^{2}$ \\ ${ }^{1}$ Program Studi Teknik Industri, Universitas Trisakti \\ ${ }^{2}$ Program Studi Teknik Industri, UniversitasTarumanagara \\ e-mail: michelle_melsha@yahoo.com
}

\begin{abstract}
ABSTRAK
PT. Gaya Motor merupakan perusahaan manufaktur mobil BMW di Indonesia. Penurunan permintaan membuat PT. Gaya Motor berencana untuk meningkatkan efisiensi dari lini sehingga peningkatan kapasitas produksi dari 9 unit/per hari menjadi 11 unit/hari dapat tercapai. Penelitian ini bertujuan untuk meningkatkan kapasitas produksi dan efisiensi lini trimming yang memiliki efisiensi lini terendah sebesar $81 \%$ karena waktu antar stasiun kerja yang tidak seimbang, dengan perancangan stasiun kerja yang tepat menggunakan metode Moodie Young, serta mengidentifikasi performansi lini setelah dan sebelum usulan perbaikan yang dilakukan dengan menggunakan software Pro Model. Efisiensi lini trimming untuk kapasitas saat ini adalah sebesar 9 unit/hari adalah 81\%, sedangkan efisiensi lini trimming dengan metode Moodie Young untuk kapasitas 11 unit/hari menghasilkan peningkatan efisiensi lini menjadi 94\% dengan penambahan 1 operator. Output rancangan stasiun kerja untuk kapasitas 11 unit/hari yang didapat dari hasil running software Pro Model selama 20 jam memiliki peningkatan output jika dibandingkan dengan output dari rancangan stasiun kerja untuk kapasitas 9 unit/hari tetapi peningkatan tersebut kurang signifikan sehingga masih diperlukan beberapa usulan perbaikan agar peningkatan kapasitas benar-benar tercapai.
\end{abstract}

Kata kunci: Keseimbangan Lini, Efisiensi Lini, Kapasitas, Simulasi, Output

\begin{abstract}
PT. Gaya Motor is a BMW car manufacturing companies in Indonesia. Decline in demand makes PT. Gaya Motor has a plan to improve the efficiency of the line so that the increase in the production capacity of 9 units/per day to 11 units/day can be achieved. This study aims to increase production capacity and efficiency of trimming line which has the lowest efficiency because the time between work stations are not balanced, the right design of work stations is to use the Moodie Young method, and identify performance line before and after the proposed repairs are carried out using the software Pro Model. Efficiency trimming line for current capacity 9 units/day was 81\%, while the efficiency line using Moodie Young method for capacity 11 units/day was 94\% with adding 1 operator. Output from the design of work stations for a capacity of 11 units/day were obtained from the results of running software Pro Model for 20 hours had an increased output compared to the output from the design of work stations for a capacity of 9 units/day but the increase is less significant that it still needed some of the proposed improvements to increased capacity actually achieved.
\end{abstract}

Keywords : line balancing, line efficiency, capacity, simulation, output

\section{PENDAHULUAN}

PT. Gaya Motor merupakan salah satu perusahaan yang bergerak di bidang industri manufaktur mobil, salah satunya dalah mobil BMW yang berlokasi di Sunter, Jakarta Utara. Pada tahun ini, terjadi penurunan permintaan per bulan pada mobil BMW menyebabkan jumlah produksinya menurun. Oleh karena itu, perlu dilakukan penyeimbangan lini untuk mendapatkan tingkat efisiensi yang tinggi.

PT. Gaya Motor berencana untuk meningkatkan kapasitas produksi untuk BMW dari 9 unit/hari menjadi 11 unit/hari, tetapi memiliki hambatan karena waktu yang tidak seimbang pada setiap stasiun kerja di lini trimming. Hal tersebut membuat perusahaan membutuhkan alternatif-alternatif perbaikan sistem kerja untuk mencapai target produksi yang direncanakan.

Peningkatan kapasitas produksi dan efisiensi lini trimming BMW dapat dilakukan dengan metode keseimbangan lini, yaitu metode Moodie Young. Metode Moodie Young merupakan suatu metode yang dapat 
menghasilkan tingkat efisiensi lini yang tertinggi di antara metode-metode keseimbangan lini yang lain, seperti metode Kilbridge-Wester, metode Helgeson-Birnie, dan metode J-Wagon [3].

Simulasi dengan software Pro Model digunakan untuk menganalisis peningkatan kapasitas yang terjadi pada lini trimming setelah dilakukan beberapa usulan perbaikan. Pro Model merupakan suatu software yang terfokus pada utilisasi sumber daya, kapasitas produksi, produktivitas, tingkat persediaan, bottlenecks, dan pengukuran performansi lainnya [2]. Hal tersebut yang membuat Pro Model sangat cocok untuk memvisualisasikan sistem produksi pada lini trimming BMW dan dapat memperlihatkan peningkatan kapasitas setelah dilakukan beberapa perbaikan.

Tujuan penelitian ini untuk memperbaiki performansi lini karena tidak seimbangnya waktu untuk setiap stasiun kerja dengan merancang stasiun kerja yang tepat menggunakan metode Moodie Young, meningkatkan kapasitas produksi dengan beberapa usulan perbaikan seperti pertambahan jam lebur atau operator, serta menganalisis peningkatan kapasitas produksi dari sistem produksi BMW dengan menggunakan software Pro Model.

\section{METODOLOGI PENELITIAN}

Adapun langkah-langkah penelitian adalah sebagai berikut:

Uji Kenormalan Data

Uji kenormalan data dilakukan untuk mengetahui apakah data yang diperoleh berdistribusi normal atau tidak [1]. Uji kenormalan data dapat dilakukan dengan uji kolmogorov-smirnov. Metode ini merupakan metode uji kenormalan yang paling popular [3]. Uji Kolmogorov-Smirnov terhadap kenormalan data dapat dihitung dengan software SPSS 20.0 [4]. Berikut hipotesis untuk uji KolmogorovSmirnov:

$$
\begin{aligned}
& \mathrm{H}_{\mathrm{o}}=\text { data berdistribusi normal } \\
& \mathrm{H}_{1}=\text { data tidak berdistribusi normal }
\end{aligned}
$$

Ketentuan dari pengujian KolmogorovSmirnov:

- Jika Asymp Sig. (2-tailed) > 0,05, maka Ho

\section{diterima}

- Jika Asymp Sig. (2-tailed) < 0,05, maka Ho ditolak

\section{Uji Keseragaman Data}

Uji keseragaman data dilakukan untuk mengetahui apakah hasil pengukuran waktu cukup seragam. Data dikatakan seragam jika data tersebut berada dalam rentang batas kontrol. Batas kontrol terdiri dari dua batas yaitu Batas Kontrol Atas (BKA) dan Batas Kontrol Bawah (BKB) [5][6]. Rumus untuk menentukan Batas Kontrol Atas dan Batas Kontrol Bawah merupakan sebagai berikut:

Pengelompokkan data yang diperoleh dalam beberapa subgroup.

Hitung rata-rata dari harga rata-rata subgroup dengan

$\bar{x}=\frac{\sum x_{i}}{k}$

Keterangan:

$x_{i}$ : harga rata-rata dari subgroup ke-i

$\mathrm{k}$ : harga banyaknya subgroup yang terbentuk

Hitung standar deviasi sebenarnya dari waktu penyelesaian dengan:

$\sigma=\sqrt{\frac{\sum\left(x_{j}-\bar{x}\right)^{2}}{N-1}}$

Keterangan:

$\mathrm{N}$ : Jumlah pengamatan pendahuluan yang telah dilakukan

$x_{j}$ : waktu penyelesaian yang teramati selama pengukuran pendahuluan telah dilakukan

Hitung standar deviasi dari distribusi harga rata-rata subgroup dengan

$\sigma_{\bar{x}}=\sigma / \sqrt{n}$

Keterangan:

n : besarnya subgroup

Tentukan batas kendali atas (BKA) dan batas kendali bawah (BKB) dengan : 
$\mathrm{BKA}=\bar{x}+k \cdot \sigma_{\bar{x}}$

$\mathrm{BKB}=\bar{x}-k \cdot \sigma_{\bar{x}}$

Uji Kecukupan Data

Uji kecukupan data dilakukan untuk mengetahui apakah data yang diambil sudah cukup atau belum. Data yang akan diuji berasal dari hasil uji keseragaman data. Jika hasil perhitungan $\mathrm{N}^{\prime}<\mathrm{N}$, maka pengamatan yang dilakukan dianggap cukup. Sebaliknya jika N' $>\mathrm{N}$, maka perlu dilakukan pengamatan lagi sebanyak N' dikurang $\mathrm{N}$ [6].

$$
N^{\prime}=\left[\frac{\frac{k}{s} \sqrt{N \cdot \sum X i^{2}-\left(\sum X i\right)^{2}}}{\sum X i}\right]^{2}
$$

Keterangan:

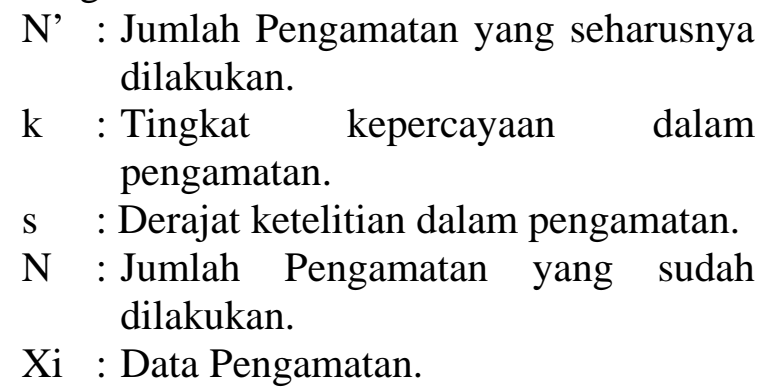

\section{Faktor Penyesuaian dan Waktu Normal}

Rating faktor penyesuaian dan waktu normal ada dasarnya digunakan untuk menormalkan waktu kerja yang diperoleh dari pengukuran kerja akibat kecepatan kerja operator yang berbeda-beda [1] [6].

$$
\text { Waktu normal }=\text { Waktu siklus } \times(1+\text { Penyesuaian })
$$

\section{Kelonggaran dan Waktu Baku}

Faktor kelonggaran yang dibutuhkan dan akan menginterupsi proses produksi ini diklasifikasikan menjadi personal allowance, fatigue allowance, dan delay allowance. Sedangkan waktu baku atau waktu standar adalah waktu normal yang telah memperhitungkan faktor kelonggaran atau allowance tersebut [1][6].

Waktu baku $=$ Waktu normal +

(\% kelonggaran $\times$ waktu normal $)$

\section{Metode Moodie Young}

Berikut merupakan penjelasan langkahlangkah dari metode Moodie Young adalah sebagai berikut [5][1]:

- Membuat matriks $\mathrm{P}$ dan matriks F berdasarkan precedence diagram. Matriks $\mathrm{P}$ dan $\mathrm{F}$ menggambarkan elemen pendahulu (P) dan elemen kerja yang mengikuti (F) untuk semua elemen kerja yang ada.

- Merancang stasiun kerja berdasarkan urutan setiap elemen pada tabel matriks $\mathrm{P}$ dan $\mathrm{F}$ dan tidak boleh melanggar precedence diagram. Waktu pengerjaan pada setiap stasiun kerja tidak boleh melebihi cycle time (CT).

- Menentukan nilai GOAL

GOAL $=($ STmax - STmin $) / 2$

- Megidentifikasi sebuah elemen kerja pada stasiun kerja yang memiliki waktu yang paling maksimum, yang memiliki waktu elemen kerja lebih kecil dari nilai GOAL, dimana elemen kerja tersebut apabila dipindah ke stasiun kerja dengan waktu yang paling minimum tanpa melanggar precedence diagram dan tidak melebihi cycle time (CT).

- Menghitung Efisiensi Lintasan

$$
\text { Efisiensi Lintasan }=\frac{\Sigma S T i}{C T \times n} \times 100 \%
$$

Berikut langkah-langkah untuk melakukan pembuatan model simulasi [2][8][9]:

- Menjalankan software Pro Model

- Menguji distribusi data dengan menggunakan Stat:Fit.

- Membuat model konseptual.

- Memasukkan background sebagai latar belakang pemodelan sistem.

- Membuat layout sistem produksi dimana proses dilakukan dengan memasukkan entities, arrivals, resources, locations, paths, processing (input hasil distribusi Stat:Fit data dan logika proses).

- Menentukan jumlah replikasi model dan running hours (jumlah jam model beroperasi) 
- Model simulasi dapat di running atau dijalankan

- Melakukan analisis output dari data statistik.

Verifikasi model bertujuan untuk membuktikan bahwa model tersebut ada atau benar [8]. Verifikasi model dilakukan dengan langkah-langkah berikut:

- Membuat model konseptual [9] .

- Melakukan pengecekan model simulasi dengan model konseptual dan logika proses. Jika model simulasi dengan model konseptual tidak terdapat perbedaan maka model simulasi terverifikasi.

- Melakukan compile pada Pro Model. Jika model dinyatakan compiled maka model simulasi terverifikasi.

Validasi model bertujuan untuk membuat model tersebut resmi diterima atau disetujui, terutama setelah memeriksanya. Validasi model dilakukan dengan membandingkan output aktual dengan output simulasi dengan menggunakan Mann Whitney-U Test yang terdapat pada software SPSS [4]. Mann Whitney-U Test dilakukan dengan membandingkan 2 hipotesis, yaitu:

$$
\begin{aligned}
\mathrm{H}_{\mathrm{o}}= & \text { tidak terdapat perbedaan antara } \\
& \text { sistem nyata dengan model simulasi } \\
\mathrm{H}_{1}= & \text { terdapat perbedaan antara sistem } \\
& \text { nyata dengan model simulasi }
\end{aligned}
$$

Ketentuan dari validasi model adalah:

- Jika Asymp Sig. (2-tailed) $>\alpha$, maka Ho diterima

- Jika Asymp Sig. (2-tailed) < $\alpha$, maka Ho ditolak

Berikut langkah-langkah untuk penelitian dapat dilihat pada Gambar 1.

\section{HASIL DAN PEMBAHASAN}

Lini trimming memiliki kendala mengenai waktu siklus yang tidak seimbang antar stasiun
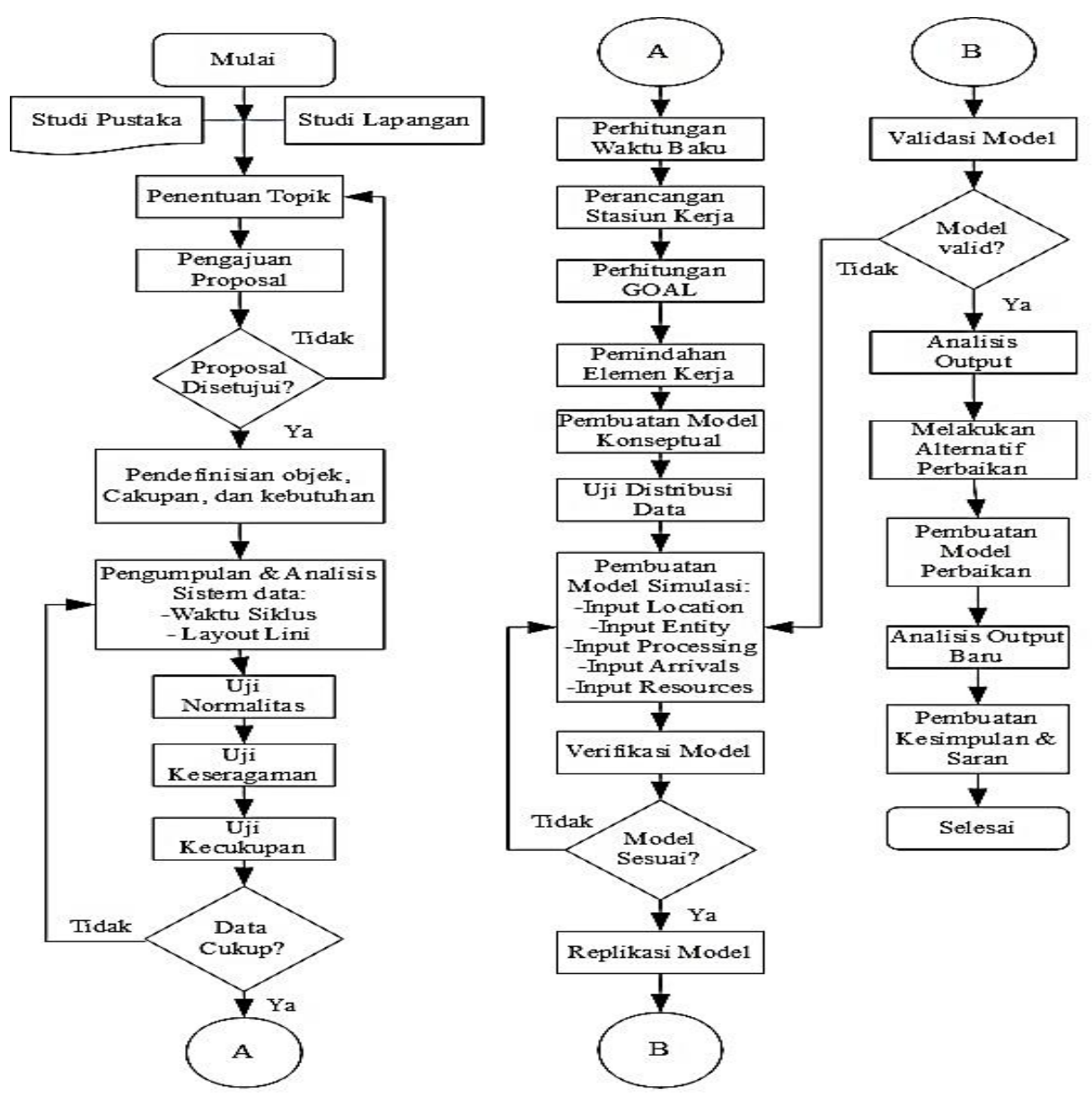

Gambar 1. Metodologi Penelitian 


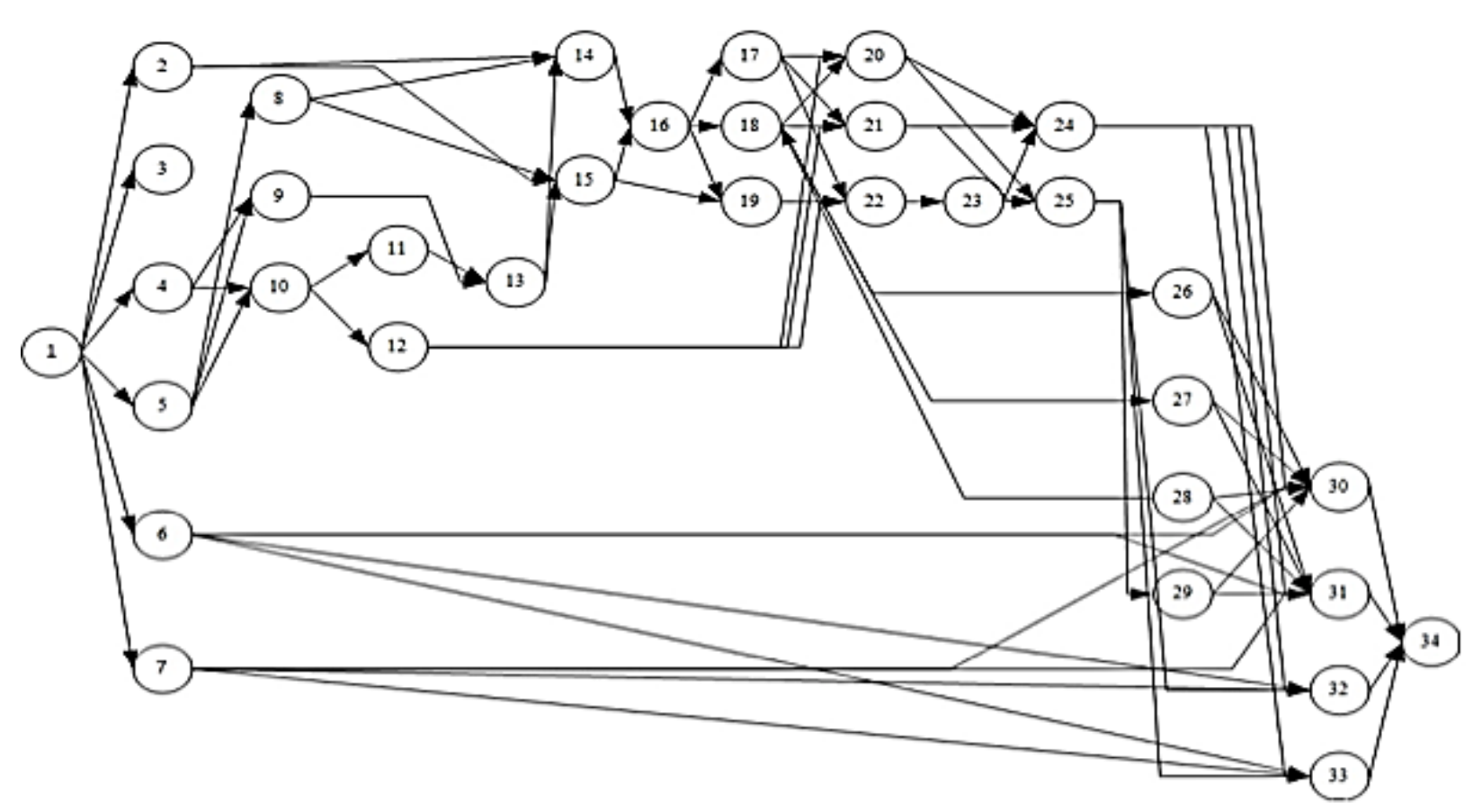

Gambar 2. Precedence Diagram

kerja. Perbedaan waktu siklus antar stasiun kerja pada lini trimming termasuk cukup besar sehingga menyebabkan efisiensi dan produktivitas pada lini trimming cukup rendah. Oleh karena itu, diperlukan pengumpulan data waktu elemen kerja pada lini trimming untuk diolah lebih lanjut menggunakan beberapa metode untuk menperoleh rancangan stasiun kerja yang tepat. Precedence diagram untuk lini trimmingdapat dilihat pada Gambar 2.

Keterangan 34 elemen kerja dan data pengamatan untuk lini trimming, dapat dilihat pada Lampiran 1 dan Lampiran 2.

Pengujian Data

Uji Kenormalan Data

Hasil uji Kolmogorov-Smirnov (uji normalitas data) diyatakan bahwa semua data waku kerja setiap elemen memiliki Asymp. Sig (2 tails) $>0,05$ sehingga seluruh data waktu kerja tiap elemen yang diperoleh berdistribusi normal. Uji Keseragaman Data

Hasil uji keseragaman data rata-rata data waktu subgrup pada 34 elemen kerja masih di dalam rentang Batas Kontrol Atas (BKA) dan Batas Kontrol Bawah (BKB) dengan tingkat keyakinan 99\%. Oleh karena itu, data waktu 34 elemen kerja yang diperoleh dinyatakan seragam.
Uji Kecukupan Data

Hasil pengujian kecukupan data untuk 34 elemen kerja, dapat dilihat pada Lampiran 5.

Hasil uji kecukupan data pada Lampiran 5 menunjukkan bahwa $\mathrm{N}>\mathrm{N}$ ', maka jumlah data yang diperoleh cukup layak untuk diolah.

\section{Cycle Time (CT)}

Berikut hasil perhitungan untuk cycle time untuk kapasitas produksi 9 unit/hari.

$\mathrm{CT}=\frac{27300}{9}=3.033,33$ detik

Berikut hasil perhitungan untuk cycle time untuk kapasitas produksi 11 unit/hari.

$\mathrm{CT}=\frac{27300}{11}=2.482 \mathrm{detik}$

\section{Rancangan Stasiun Kerja Kondisi Saat Ini}

Berikut rancangan stasiun kerja untuk kondisi saat ini dengan kapasitas produksi 9 unit/hari, dapat dilihat pada Tabel 1.

$$
\begin{aligned}
& \text { Efisiensi Lintasan } \\
& \qquad \begin{aligned}
=\frac{\Sigma S T i}{C T \times n} \times 100 \% \\
=\frac{2894,93+1883,79+\ldots+2433,43+2265,13}{3033 \times 17}=81 \%
\end{aligned}
\end{aligned}
$$


Peningkatan Kapasitas dan Efisiensi Lini Trimming dengan Metode Moodie Young dan Simulasi Promodel pada Perakitan Mobil BMW di PT. Gaya Motor

Iveline Anne Marie, Lamto Widodo dan Michelle Melsha Sugiarto

Tabel 1. Rancangan Stasiun Kerja Saat Ini

\begin{tabular}{|c|c|c|c|}
\hline Stasiun & $\begin{array}{c}\text { Elemen } \\
\text { Kerja }\end{array}$ & $\begin{array}{l}\text { Waktu } \\
\text { (detik) }\end{array}$ & Total (detik) \\
\hline \multirow{3}{*}{ T00 } & 1 & 2479.40892 & \multirow{3}{*}{2894.92704} \\
\hline & 2 & 270.45954 & \\
\hline & 3 & 145.05858 & \\
\hline \multirow{4}{*}{ T01 } & 4 & 478.98324 & \multirow{4}{*}{1883.78622} \\
\hline & 5 & 456.7131 & \\
\hline & 6 & 655.9974 & \\
\hline & 7 & 292.09248 & \\
\hline \multirow{3}{*}{ T02A } & 8 & 449.73576 & \multirow{3}{*}{3031.6069} \\
\hline & 9 & 513.0739 & \\
\hline & 10 & 2068.79724 & \\
\hline \multirow{2}{*}{ Т02B } & 11 & 1962.19368 & \multirow{2}{*}{2172.78828} \\
\hline & 12 & 210.5946 & \\
\hline T03 & 13 & 2463.63822 & 2463.63822 \\
\hline T04A & 14 & 2437.578 & 2437.578 \\
\hline T04B & 15 & 2470.84695 & 2470.84695 \\
\hline \multirow{2}{*}{ T05 } & 16 & 2085.01398 & \multirow{2}{*}{2208.02544} \\
\hline & 19 & 123.01146 & \\
\hline T06A & 17 & 2470.84695 & 2470.84695 \\
\hline \multirow{4}{*}{ T06B } & 18 & 1880.91882 & \multirow{4}{*}{2973.68496} \\
\hline & 26 & 154.61658 & \\
\hline & 27 & 299.0061 & \\
\hline & 28 & 639.14346 & \\
\hline \multirow{3}{*}{ T07 } & 22 & 2270.05686 & \multirow{3}{*}{2947.78278} \\
\hline & 20 & 236.30562 & \\
\hline & 21 & 441.4203 & \\
\hline T08 & 23 & 2185.21368 & 2185.21368 \\
\hline \multirow{2}{*}{ T09 } & 25 & 1924.5033 & \multirow{2}{*}{1996.47504} \\
\hline & 24 & 71.97174 & \\
\hline \multirow{3}{*}{ T10 } & 29 & 2058.37902 & \multirow{3}{*}{2546.02818} \\
\hline & 32 & 293.112 & \\
\hline & 33 & 194.53716 & \\
\hline T11A & 30 & 2414.09592 & 2414.09592 \\
\hline T11B & 31 & 2433.43494 & 2433.43494 \\
\hline T12 & 34 & 2265.13017 & 2265.13017 \\
\hline
\end{tabular}

\section{Metode Moodie Young untuk Kapasitas 9 unit/hari}

Berikut rancangan stasiun kerja untuk kondisi saat ini dengan kapasitas produksi 9 unit/hari menggunakan metode Moodie Young, dapat dilihat pada Tabel 2.

\section{Efisiensi Lintasan}

$$
\begin{aligned}
& =\frac{\Sigma S T i}{C T \times n} \times 100 \% \\
& =\frac{2958,39+2783,13+\ldots+2412,15+2265,13}{3033 \times 17} \\
& =81 \%
\end{aligned}
$$

\begin{tabular}{|c|c|c|c|}
\hline Stasiun & $\begin{array}{c}\text { Elemen } \\
\text { Kerja }\end{array}$ & $\begin{array}{l}\text { Waktu } \\
\text { (detik) }\end{array}$ & Total (detik) \\
\hline \multirow{2}{*}{ T00 } & 1 & 2479.40892 & \multirow{2}{*}{ 2958.39216 } \\
\hline & 4 & 478.98324 & \\
\hline \multirow{7}{*}{ T01 } & 6 & 655.9974 & \multirow{7}{*}{2783.13076} \\
\hline & 5 & 456.7131 & \\
\hline & 9 & 513.0739 & \\
\hline & 8 & 449.73576 & \\
\hline & 7 & 292.09248 & \\
\hline & 2 & 270.45954 & \\
\hline & 3 & 145.05858 & \\
\hline \multirow{2}{*}{ T02A } & 10 & 2068.79724 & \multirow{2}{*}{ 2279.39184 } \\
\hline & 12 & 210.5946 & \\
\hline T02B & 11 & 1962.19368 & 1962.19368 \\
\hline T03 & 13 & 2463.63822 & 2463.63822 \\
\hline \multirow{2}{*}{ T04A } & 15 & 2470.84695 & \multirow{2}{*}{2593.85841} \\
\hline & 19 & 123.01146 & \\
\hline T04B & 14 & 2437.578 & 2437.578 \\
\hline T05 & 16 & 2085.01398 & 2085.01398 \\
\hline T06A & 17 & 2459.7513 & 2459.7513 \\
\hline \multirow{3}{*}{ T06B } & 18 & 1880.91882 & \multirow{3}{*}{2961.48258} \\
\hline & 28 & 639.14346 & \\
\hline & 21 & 441.4203 & \\
\hline \multirow{4}{*}{ T07 } & 22 & 2270.05686 & \multirow{4}{*}{2959.98516} \\
\hline & 27 & 299.0061 & \\
\hline & 20 & 236.30562 & \\
\hline & 26 & 154.61658 & \\
\hline \multirow{2}{*}{ T08 } & 23 & 2185.21368 & \multirow{2}{*}{2257.18542} \\
\hline & 24 & 71.97174 & \\
\hline T09 & 29 & 2058.37902 & 2058.37902 \\
\hline T10 & 31 & 2433.43494 & 2433.43494 \\
\hline T11A & 30 & 2414.09592 & 2414.09592 \\
\hline \multirow{3}{*}{ Т11B } & 25 & 1924.5033 & \multirow{3}{*}{2412.15246} \\
\hline & 32 & 293.112 & \\
\hline & 33 & 194.53716 & \\
\hline $\mathrm{T} 12$ & 34 & 2265.13017 & 2265.13017 \\
\hline
\end{tabular}

Tabel 2. Moodie Young Stasiun Lama

\section{Metode Moodie Young untuk Kapasitas 11 unit/hari}

Berikut rancangan stasiun kerja untuk kondisi saat ini dengan kapasitas produksi 11 unit/hari menggunakan metode Moodie Young, dapat dilihat pada Tabel 3.

Efisiensi Lintasan

$$
\begin{aligned}
& =\frac{\Sigma S T i}{C T \times n} \times 100 \% \\
& =\frac{2479,41+2476,86+\ldots+2414,10+2265,13}{2482 \times 40} \\
& =94 \%
\end{aligned}
$$


Tabel 3. Moodie Young Stasiun Baru

\begin{tabular}{|c|c|c|c|}
\hline Stasiun & $\begin{array}{c}\text { Elemen } \\
\text { Kerja }\end{array}$ & Waktu (detik) & Total (detik) \\
\hline T00 & 1 & 2479.40892 & 2479.40892 \\
\hline \multirow{5}{*}{ T01 } & 6 & 655.9974 & \multirow{5}{*}{2476.86012} \\
\hline & 4 & 478.98324 & \\
\hline & 5 & 456.7131 & \\
\hline & 9 & 593.0739 & \\
\hline & 7 & 292.09248 & \\
\hline \multirow{2}{*}{ T02A } & 10 & 2068.79724 & \multirow{2}{*}{2339.25678} \\
\hline & 2 & 270.45954 & \\
\hline \multirow{2}{*}{ Т02B } & 11 & 1962.19368 & \multirow{2}{*}{2411.92944} \\
\hline & 8 & 449.73576 & \\
\hline T03 & 13 & 2463.63822 & 2463.63822 \\
\hline T04A & 15 & 2470.84695 & 2470.84695 \\
\hline T04B & 14 & 2437.578 & 2437.578 \\
\hline \multirow{3}{*}{ T05 } & 16 & 2085.01398 & \multirow{3}{*}{2440.66716} \\
\hline & 12 & 210.5946 & \\
\hline & 3 & 145.05858 & \\
\hline T06A & 17 & 2459.7513 & 2459.7513 \\
\hline \multirow{4}{*}{ Т06B } & 18 & 1880.91882 & \multirow{4}{*}{2457.55296} \\
\hline & 27 & 299.0061 & \\
\hline & 26 & 154.61658 & \\
\hline & 19 & 123.01146 & \\
\hline T07 & 22 & 2270.05686 & 2270.05686 \\
\hline \multirow{2}{*}{ T08 } & 23 & 2185.21368 & \multirow{2}{*}{2421.5193} \\
\hline & 20 & 236.30562 & \\
\hline \multirow{3}{*}{ T09 } & 28 & 639.14346 & \multirow{3}{*}{1152.5355} \\
\hline & 21 & 441.4203 & \\
\hline & 24 & 71.97174 & \\
\hline \multirow{3}{*}{$\mathrm{T} 10$} & 25 & 1924.5033 & \multirow{3}{*}{2412.15246} \\
\hline & 32 & 293.112 & \\
\hline & 33 & 194.53716 & \\
\hline T11A & 29 & 2058.37902 & 2058.37902 \\
\hline T11B & 31 & 2433.43494 & 2433.43494 \\
\hline T12 & 30 & 2414.09592 & 2414.09592 \\
\hline T13 & 34 & 2265.13017 & 2265.13017 \\
\hline
\end{tabular}

\section{Model Konseptual}

Berikut model konseptual untuk sistem nyata, dapat dilihat pada Gambar 3.

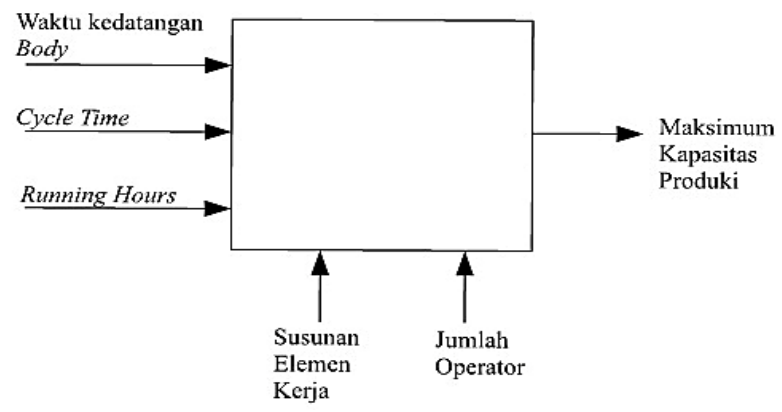

Gambar 3. Model Konseptual

Berikut merupakan model simulasi dari rancangan stasiun kerja untuk sistem nyata dengan 17 operator dengan melakukan input (build) location,entities, resources, processing, dan paths, dapat dilihat pada Gambar 4.

Berikut hasil replikasi output (B17) model sebanyak 10 kali dengan running hours selama 20 jam untuk dihasilkan 9 unit.

Verifikasi model dilakukan dengan pengecekan sistem nyata dengan model konseptual dan didapatkan hasil bahwa sistem nyata dengan model konseptual memiliki persamaan, serta dilakukan compile model simulasi pada software Pro Model dan didapatkan hasil model simulasi compiled. Hal tersebut menunjukkan bahwa model telah terverifikasi. Hasil compiled model simulasi dapat dilihat pada Gambar 5.

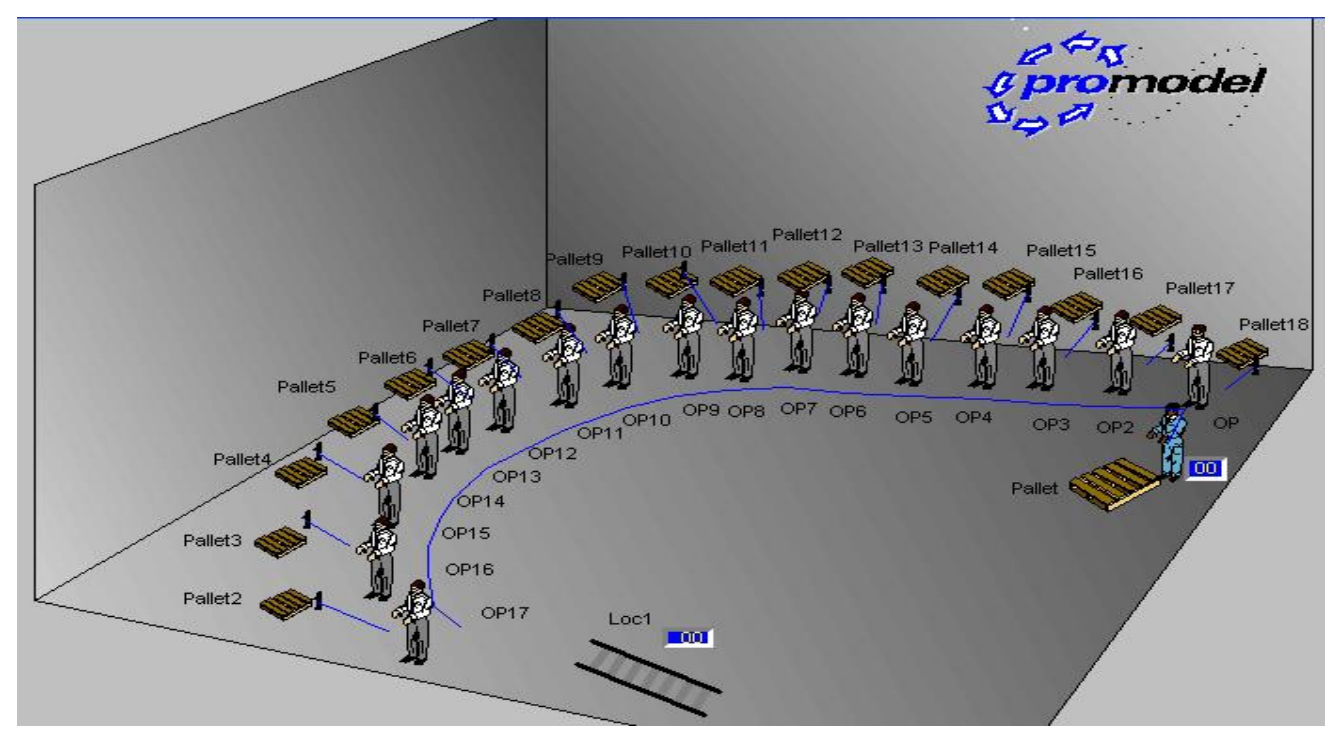

Gambar 4. Model Sistem Nyata 


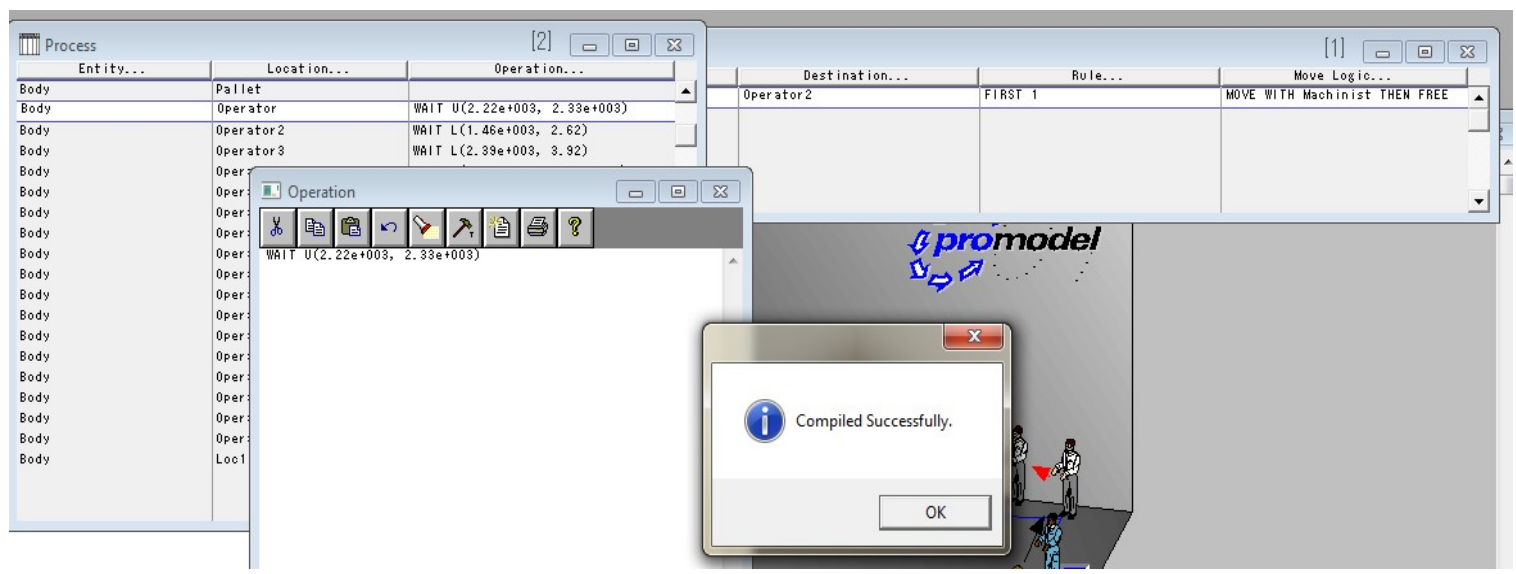

Gambar 5. Verifikasi Model Simulasi dengan Pro Model

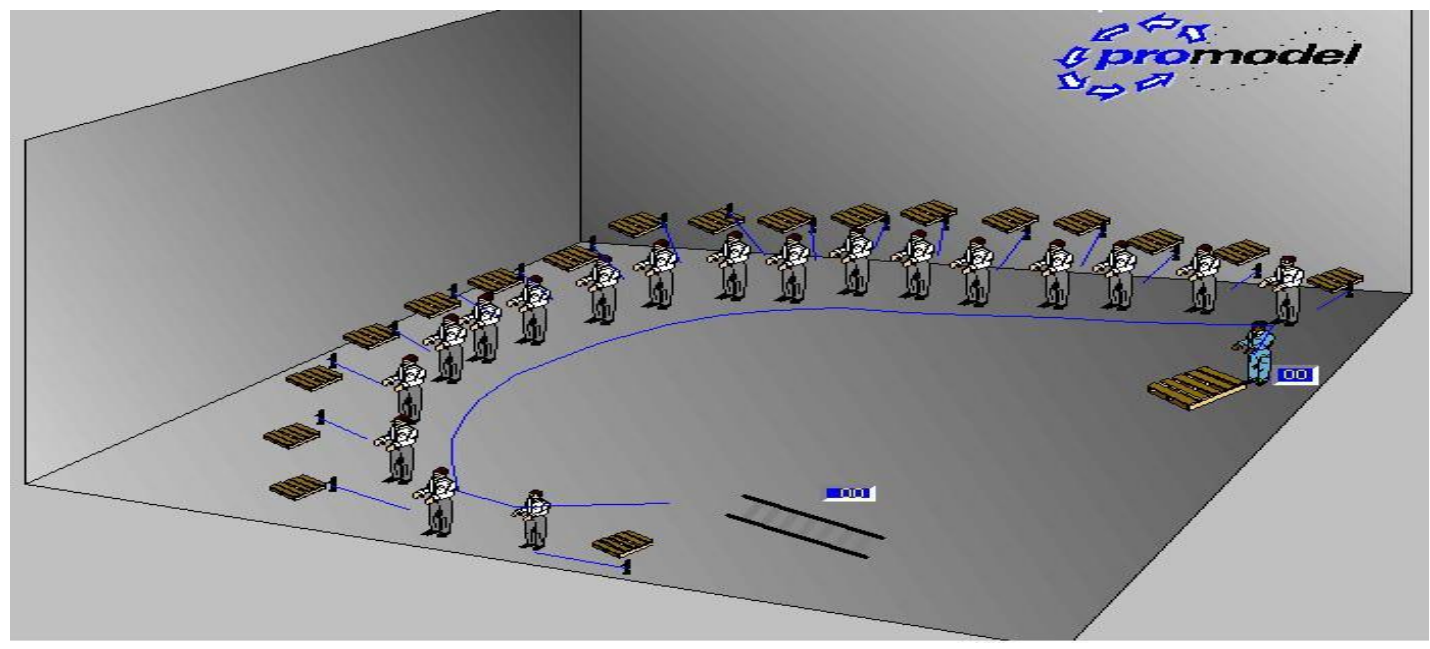

Gambar 6. Model Simulasi Moodie Young

Validasi model dilakukan dengan menggunakan Mann Whitney- $U$ Test untuk membandingkan output sistem nyata dengan output model simulasi sistem. Hasil pengujian Mann Whitney-U dapat dilihat pada Tabel 4.

\begin{tabular}{cc}
\multicolumn{2}{c}{ Tabel 4. Hasil Mann Whitney-U Test } \\
\hline & Output \\
\hline Mann-Whitney $U$ & 7.500 \\
Wilcoxon W & 22.500 \\
Z & -1.491 \\
Asymp. Sig. (2-tailed) & .136 \\
Exact Sig. $\{2 *(1-$ Tailed Sig.)] & $.310^{b}$ \\
\hline Grouping Variable: Grup &
\end{tabular}

a. Grouping Variable: Grup

Hasil Mann Whitney-U Test di atas menunjukkan bahwa Asymp. Sig. (2-tailed) > 0.05 berarti sistem nyata dengan model simulasi sistem tidak memiliki perbedaan. Berikut merupakan model simulasi hasil rancangan stasiun kerja dengan metode Moodie Young untuk kapasitas 11 unit/hari dengan 18 operator, dapat dilihat pada Gambar 6.

Berikut hasil replikasi model sebanyak 10 kali dengan running hours selama 20 jam dapat dilihat pada Tabel 5.

\section{KESIMPULAN}

Efisiensi lini trimming untuk kapasitas saat ini sebesar 9 unit/ hari adalah 81\%, efisiensi lini trimming dengan metode Moodie Young sebesar 9 unit/ hari adalah 81\%. Oleh karena itu, diperlukan rancangan stasiun kerja dengan metode Moodie Young untuk kapasitas 11 unit/hari dan dihasilkan efisiensi lini trimming mengalami peningkatan menjadi 94\%. Output rancangan stasiun kerja untuk kapasitas 11 unit/hari yang didapat dari hasil running software Pro Model selama 20 jam memiliki peningkatan output jika dibandingkan dengan output dari rancangan stasiun kerja untuk 
Tabel 5. Hasil Replikasi Model Simulasi

\begin{tabular}{|c|c|c|c|c|c|c|c|c|}
\hline \multicolumn{9}{|c|}{ Entity Activity for promodels2 (10 replications) } \\
\hline Name & $\begin{array}{r}\text { Replicatio } \\
\mathbf{n}\end{array}$ & $\begin{array}{c}\text { Total } \\
\text { Exits }\end{array}$ & $\begin{array}{r}\text { Current Qty In } \\
\text { System }\end{array}$ & $\begin{array}{l}\text { Avg Time In } \\
\text { System (MIN) }\end{array}$ & $\begin{array}{r}\text { Avg Time In Move } \\
\text { Logic (MIN) }\end{array}$ & $\begin{array}{r}\text { Avg Time Wait For } \\
\text { Res (MIN) }\end{array}$ & $\begin{array}{r}\text { Avg Time In } \\
\text { Operation (MIN) }\end{array}$ & $\begin{array}{r}\text { Avg Time } \\
\text { Blocked (MIN) }\end{array}$ \\
\hline B17 & 8 & 0.00 & 1.00 & 0.00 & 0.00 & 0.00 & 0.00 & 0.00 \\
\hline B17 & 9 & 0.00 & 1.00 & 0.00 & 0.00 & 0.00 & 0.00 & 0.00 \\
\hline B17 & 10 & 0.00 & 0.00 & 0.00 & 0.00 & 0.00 & 0.00 & 0.00 \\
\hline B18 & 1 & 12.00 & 0.00 & 627.09 & 12.04 & 3.09 & 535.42 & 76.54 \\
\hline B18 & 2 & 11.00 & 0.00 & 623.42 & 11.65 & 3.08 & 549.86 & 58.83 \\
\hline B18 & 3 & 10.00 & 0.00 & 691.45 & 10.55 & 3.06 & 526.52 & 151.31 \\
\hline B18 & 4 & 13.00 & 0.00 & 626.95 & 11.10 & 3.10 & 516.78 & 95.97 \\
\hline B18 & 5 & 10.00 & 0.00 & 703.06 & 9.77 & 3.06 & 541.50 & 148.73 \\
\hline B18 & 6 & 9.00 & 0.00 & 677.07 & 10.53 & 3.05 & 547.29 & 116.19 \\
\hline B18 & 7 & 11.00 & 0.00 & 664.73 & 11.04 & 3.08 & 523.31 & 127.29 \\
\hline B18 & 8 & 11.00 & 0.00 & 697.38 & 10.88 & 3.08 & 535.16 & 148.26 \\
\hline B18 & 9 & 11.00 & 0.00 & 625.88 & 9.74 & 3.08 & 502.84 & 110.22 \\
\hline B18 & 10 & 11.00 & 0.00 & 634.77 & 10.59 & 3.08 & 555.00 & 66.10 \\
\hline
\end{tabular}

kapasitas 9 unit/hari tetapi peningkatan tersebut kurang signifikan sehingga masih diperlukan beberapa usulan perbaikan, seperti penambahan operator dan overtime agar peningkatan kapasitas benar-benar tercapai.

\section{DAFTAR PUSTAKA}

[1] Intan Permatasari (www.academia.edu/ 9640548/Promodel), "Promodel", Academia, diakses 19 September 2015.

[2] Riyanto, Agus, Simulasi Sistem Antrian Menggunakan Pro Model di RS Hasan Sadikin Bandung, Bandung, 2014, pp. 712.

[3] Boediono dan Wayan Koster. 2002. Teori dan Aplikasi Statistika dan Probabilitas. Bandung: PT Remaja Rosdakarya.

[4] Eben Henry. "Analisa Peningkatan Kapasitas Produksi pada Line Assembling Transmisi PT. X dengan Metode Line Balancing”. Skripsi S.T., Universitas Indonesia, Depok, 2011.

[5] Santoso, Singih. 2015. Menguasai SPSS 22. Jakarta: PT Elex Media Komputindo
[6] Gozali, Lina, Andres, dan Feriyatis. Penentuan Jumlah Tenaga Kerja Dengan Metode Keseimbangan Lini Pada Divisi Plastic Painting PT. XYZ. Jurnal Ilmiah Teknik Industri. Vol. 3 No. 1 (2015): 1017.

[7] Sutalaksana, Iftikar, Ruahana, dan Jann. 2006. Teknik Perancangan Sistem Kerja.

[8] Harrel, Charles, B.K. Ghosh, dan R.O. Bowden, Jr. Simulation Using Promodel Second Edition. New York, USA: McGraw-Hill, Inc.

[9] M. Nashihun Ulwan (www.portalstatistik.com/2014/02/uji-normalitasdengan- menggunakan-spss.html), "Uji Normalitas dengan Menggunakan SPSS (Normality Test)", Portal Statistik, diakses 12 September 2015. Bandung: Penerbit ITB. 